\title{
Aplikasi untuk Sistem Administrasi Travel Agent
}

\author{
Yudhianto Setiono, Departemen Sistem Informasi, Institut Sains dan Teknologi Terpadu Surabaya
}

\begin{abstract}
Abstrak - Travel agent adalah suatu jasa perantara yang dimana menghubungkan antara satu produsen jasa dengan konsumen. Salah satu faktor utama dari pelayanan yang baik adalah penggunaan sistem yang tepat, cepat dan akurat. Sebagian besar travel agent masih menggunakan cara manual untuk melakukan pencatatan transaksi penjualan maupun pada saat melakukan perhitungan laba rugi. Pada travel agent, sehingga sistem yang digunakan saat ini dinilai sangat kurang efektif dan tidak akurat. Untuk itulah, saya membuat suatu program yang dapat membantu meminimalkan terjadinya kesalahan pada pencatatan transaksi serta dapat membantu mengambil keputusan pada saat proses transaksi berlangsung. Sehingga bisa mendapatkan data-data yang diinginkan secara cepat dan akurat pada. Aplikasi untuk sistem administrasi travel agent ini dibuat dengan menggunakan software aplikasi Visual Studio, DevExpress dan MySQL sebagai databasenya, untuk menangani data-data dan query yang diperlukan didalam perusahaan agar dapat menghasilkan data laporan yang diinginkan. Pada Penelitian ini, aplikasi sistem administrasi travel agent dibuat untuk mempermudah perusahaan melakukan penyimpanan data kedalam aplikasi, meningkatkan kinerja pemilik agent travel dan integrasi informasi data pada travel agent. Sistem transaksi penjualan yang telah terkomputerisasi akan langsung dapat menghasilkan data-data laporan yang diperlukan yang telah di masukkan kedalam database sistem. Dengan adanya modulmodul yang terintegrasi menjadi satu kesatuan, maka setiap travel agent dapat menjalankan bisnisnya dengan lebih aman dan terkendali, serta dapat membuat keputusan management yang tepat dengan melihat laporan-laporan pembelian yang ada. Hal ini sangat dibutuhkan untuk travel agent terutama bila ingin membuat laporan penjualan dan perhitungan laba dan rugi pada agent.
\end{abstract}

Kata Kunci-Agen Perjalanan, Penjualan Tiket.

\section{Pendahuluan}

$\mathrm{P}$ erkembangan ilmu pengetahuan dan teknologi yang sangat pesat semakin mendorong manusia untuk meningkatkan bahkan menciptakan suatu teknologi baru yang lebih bermanfaat dan efisiensi bagi umat manusia. Perkembangan dan kemajuan yang pesat dialami oleh negara-negara yang menguasai teknologi informasi pada era globalisasi ini termasuk indonesia, sehingga mengakibatkan negara-negara yang tidak memiliki infrastruktur teknologi informasi yang cukup canggih akan tertinggal jauh di belakang.

Yudhianto Setiono, Departemen Sistem Informasi, Institut Sains dan Teknologi Terpadu Surabaya, Surabaya, Jawa Timur, Indonesia (e-mail: yudhianto11@gmail.com)
Sebelumnya maraknya teknologi, para pelaku usaha tersebut hanya memiliki sistem yang terbatas dengan menggunakan sistem manual masih menggunakan kertas sebagai media pecatatan dan pendataan customer sehingga membutuhkan tingkat ketelitian yang tinggi bila sudah terdapat banyak data customer yang masuk dalam perusahaan. Sistem secara menual juga dirasa kurang efisiensi oleh para pelaku usaha travel agent tersebut dikarenakan harus membutuhkan banyak kertas ataupun media lainnya yang terpisah seperti microsoft excel, word untuk mendata ditambah lagi ketika untuk melakukan perhitungan dan pendataan nama customer pegawai membutuhkan ketelitian terkadang juga terjadi kesalahan dalam proses pembuatannya jadwal laporan perjalanan dan perhitungan total keseluruhan hasil dari pembelian dari customer.

Dikarenakan teknologi sudah berkembang pada era saat ini dan berbekal dari teknologi informasi dari pelaku usaha, oleh karena itu saya memutuskan untuk membuat aplikasi untuk perusahaan travel agent yang akan dapat memudahkan untuk digunakan digunakan pada agent perjalanan tersebut. Aplikasi tersebut dibuat dalam bentuk aplikasi dekstop yang berbasis sistem operasi windows. Sehingga diharapkan untuk memberi kemudahan untuk pemakai aplikasi dari segi teknologi ini dapat benar-benar diterapkan dan dimanfaatkan oleh pemilik pengusaha travel agent dan bisa membuat waktu pegawai lebih efisien dan bisa lebih efektif dari segi waktu, tenagam dan biaya dalam melakukan perhitungan maupun pendataan customer dan melakukan cetak data nota invoice maupun ketika membuat jadwal laporan perjalanan.

Tujuan

a) Untuk Pembeli:

- Memudahkan pembeli untuk melakukan pencarian tiket dan sekaligus proses untuk melakukan reservasi hotel bila terdapat penambahan, dapat melayani pembelian tiket untuk keberangkatan dan sekaligus tiket untuk pulang dapat dilakukan dalam satu kali pembelian dengan mendapatkan detail invoice tiket pembelian yang telah dibeli.

- Membantu pembeli pada saat melakukan proses pembelian paket wisata dapat sekaligus melakukan penambahan hotel dan transportasi dan penambahan lainnya dalam satu kali pembelian.

- Membantu pembeli agar dapat melihat perbandingan harga dan jenis fasilitas hotel maupun transportasi sebelum melakukan pembelian. 
b) Untuk Pemilik:

- Memberikan kemudahan pemilik travel agent dalam menjalankan usahanya khususnya dalam laporan penjualan dan dapat mengetahui laba dan rugi pada agent.

- Lebih mudah dalam menawarkan paket wisata yang tersedia pada agent termasuk juga menawarkan tiket yang sedang tersedia pada agent travel.

\section{TEORI DASAR}

\section{A. Prototyping}

Prototyping adalah salah satu proses pendekatan dalam pengembangan sistem yang secara langsung yang mendemonstrasikan bagaimana sebuah sistem atau komponen-komponen sistem akan bekerja dalam lingkungannya sebuah tahapan konstruksi aktual awal yang dilakukan berikut merupakan gambar proses prototyping pada tahap awal.

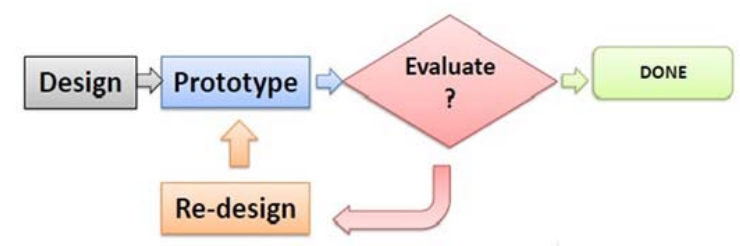

Gambar. 1. Proses Prototyping

\section{B. Prototype}

Prototype merupakan model dari software yang mensimulasikan produk sesungguhnya namun dengan fungsionalitas yang terbatas. Secara umum, prototype juga digunakan untuk merevisi desain untuk tujuan mengurangi biaya melalui optimalisasi dan perbaikan, terutama ketika desain diulang beberapa kali untuk mencari tahu masalah dan bagaimana cara menyelesaikannya.

\section{Black-box testing}

Black-box testing merupakan suatu sekenario uji coba yaitu yang juga dikenal sebagai Behavioral Testing. Adalah metode untuk suatu pengujian perangkat lunak yang dimana struktur internal atau desain dan implementasi dari item yang diuji tidak diketahui oleh tester. Tes-tes ini bias fungsional ataupun non- fungsional, meskipun biasanya disebut fungsional. Metode ini dinamai demikian karena program dari perangkat lunak, dari sudut pandang penguji dan umum, seperti berbentuk illustrasi sebuah kotak hitam, yang dimana orang tidak dapat melihat kedalamnya.

\section{ANALISA DAN DESAIN SiSTEM}

Pada bab analisa dan desain sistem akan dijelaskan mengenai sistem cara kerja dari "Aplikasi Untuk Sistem Administrasi Travel Agent". Analisa akan dilakukan dengan mencari fakta sebanyak-banyaknya berupa analisa dari sistem aplikasi travel agent yang sudah ada sebelumnya, sedangkan desain sistem akan menjelaskan secara rinci. Sistem terdiri dari desain arsitektural, desain database.

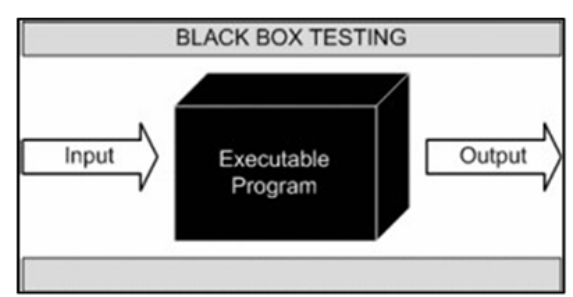

Gambar. 2. Black-Box Testing

Hal tersebut dapat membantu user untuk lebih mengerti alur cara kerja pada sistem aplikasi untuk administrasi travel agent ini.

a) Gambaran umum sistem

Pada sub bab ini akan menjelaskan secara singkat mengenai sistem aplikasi untuk sistem administrasi travel agent yang akan dibuat. Pada sistem aplikasi dibagi menjadi 2 proses yaitu admin dan terdapat pegawai.

b) Desain database

Dalam subbab desain database ini akan dijelaskan struktur database dari aplikasi administrasi pada travel agent yang digunakan didalam aplikasi.

c) Desain table

Akan dijelaskan mengenai tabel-tabel yang ada di dalam database yang digunakan dan diperlukan di dalam aplikasi untuk sistem administrasi travel agent.

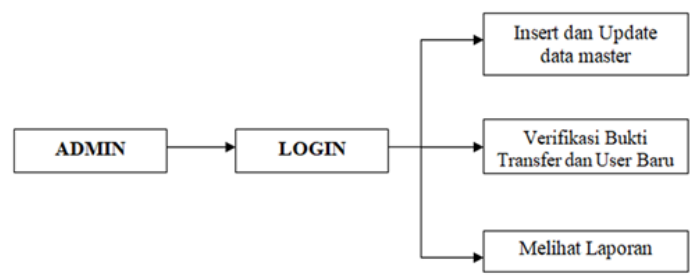

Gambar. 3. Arsitektur Sistem

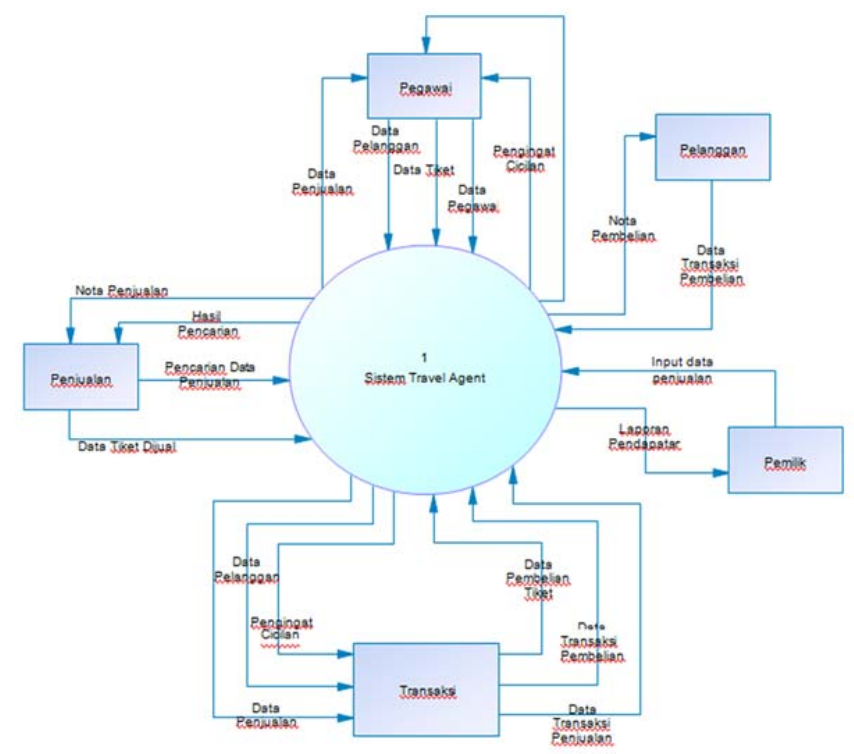

Gambar. 4. Rancangan sistem travel agent 


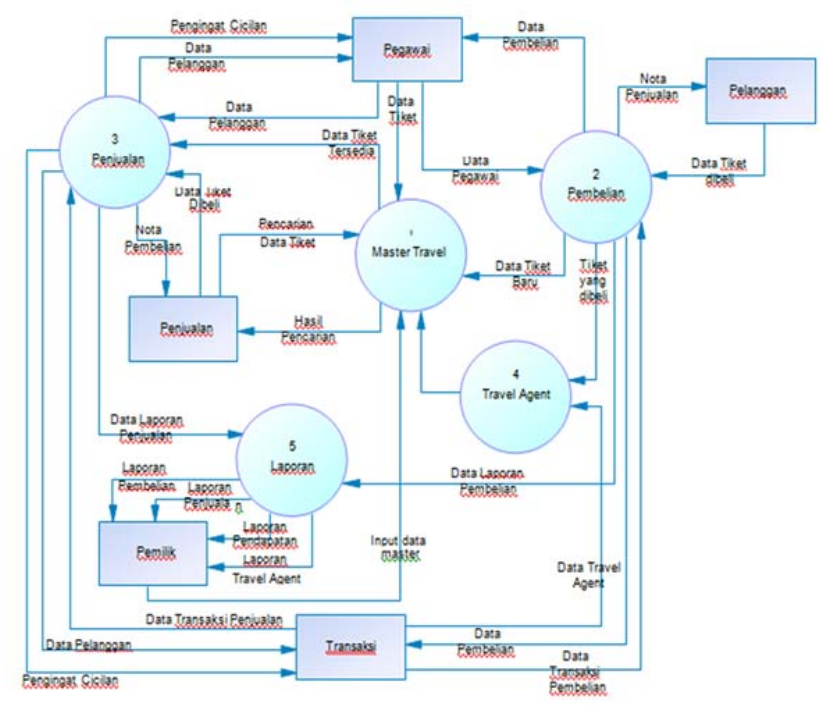

Gambar. 5. DFD sistem travel agent

\section{PROTOTYPE I}

Dalam menunjukan rancangan program untuk memenuhi kebutuhan sistem. Prototype ini akan menggambarkan sistem secara lebih rinci, memiliki interaksi penuh dengan pengguna pemilik dari sistem travel agent dengan pengembang. Prototype yang dapat mewakilkan fungsifungsi inti dari sistem sehingga dapat mensimulasikan sebagian besar fungsi dari penggunaan sistem pada Penelitian dan mempunyai penampilan yang mirip dengan aplikasi yang sudah ada sebenarnya dan terdapat penambahan fungsi baru pada sistem.

Fitur-fitur:

- Penjualan Invoice Tiket

Invoice tiket merupakan fitur dimana digunakan untuk melakukan penjualan berbagai macam tiket seperti tiket pesawat, kereta api, bus, dan lainnya, pada invoice tiket ini pembeli diwajibkan melakukan pembayaran langsung lunas dikarenakan untuk melakukan pembelian tiket dari agent supplier dengan jadwal yang keberangkatan yang telah ditentukan pembeli.

- Penjualan Invoice Pesawat

Invoice tiket merupakan fitur yang digunakan hanya untuk melakukan penjualan tiket pesawat saja, customer dapat melakukan pembelian tiket pesawat secara pulang dan pergi termasuk juga jika customer terdapat penambahan paket hotel juga dapat dilakukan penambahan.

- Penjualan Invoice Tiket Kereta Api

Invoice tiket merupakan fitur yang digunakan hanya untuk melakukan penjualan tiket kereta api saja, customer dapat melakukan pembelian tiket kereta api secara pulang dan pergi termasuk juga jika customer terdapat penambahan paket hotel juga dapat dilakukan penambahan.

- Penjualan Invoice Paket

Invoice paket merupakan fitur dimana dapat dilakukan pembelian paket wisata secara rombongan wisata, maupun pembelian paket wisata secara individu atau family pack pada fitur paket wisata ini, juga dapat dilakukan pembelian tambahan untuk melakukan pembelian paket hotel yang dapat disesuaikan dengan jumlah peserta yang mengikuti wisata maupun dapat melakukan penambahan menu makanan dan tambahan lainnya mulai dari restaurant, transportasi, obyek wisata, tour guide, tour leader.

- Hasil Uji Coba Tahap Ke 1

- Terdapat beberapa hasil feedback yang dibutuhkan untuk ditambahkan pada aplikasi untuk tahap berikutnya yaitu pada prototype hasil kedua, hasil uji coba prototyping pertama ini. Merupakan hasil dari feedback dari pengguna pemilik travel agent yang akan digunakan dalam perbaikan prototype kedua pada bab selanjutnya.

Berikut merupakan contoh sekilas gambar dari menu dari user interface sistem lama, terdapat keterbatasan sistem yang hendak akan digunakan dan dirasa kurang efisien oleh pemilik dari travel agent, terkadang juga terdapat bug atau error pada aplikasi yang tidak diketahui pada aplikasi yang lama dan dibutuhkan penambahan fitur menu baru serta perbaikan bug pada proses tahap selanjutnya.

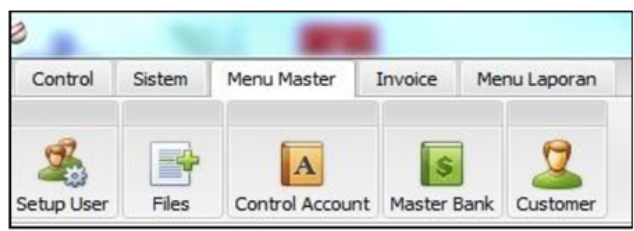

Gambar. 6. Menu Master Control

Berikut merupakan contoh sekilas gambar dari menumenu dari user interface sistem lama pada menu cetak invoice, terdapat keterbatasan menu yang hendak akan digunakan pada agen dan dibutuhkan penambahan fitur menu-menu baru pada proses tahap selanjutnya.

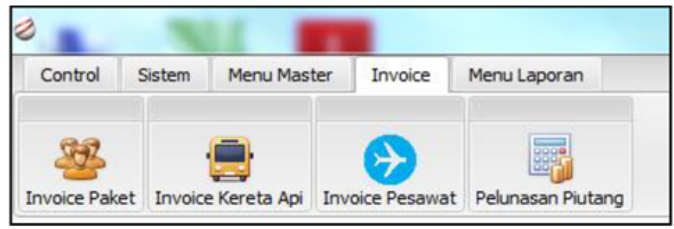

Gambar. 7. Menu Invoice

Berikut merupakan contoh sekilas gambar dari menumenu dari user interface sistem lama pada menu laporan, terdapat keterbatasan menu yang hendak akan digunakan untuk mengakses laporan penjualan dan laporan untuk melakukan pemantauan keuntungan yang didapat oleh agen dan dibutuhkan penambahan fitur menu-menu baru pada proses tahap selanjutnya.

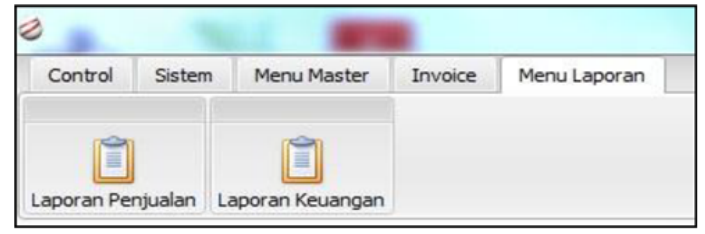

Gambar. 8. Menu Laporan 
Berikut merupakan contoh pada aplikasi agent travel pada saat melakukan proses print atau cetak invoice pengguna tidak dapat langsung melakukan cetak melainkan pengguna diharuskan melakukan preview terlebih dahulu dan cara ini dirasa kurang efisiensi oleh pemilik agent dan perlu dilakukan perbaikan pada proses tahap selanjutnya agar dapat melakukan cetak otomatis setelah melakukan input data pada aplikasi.

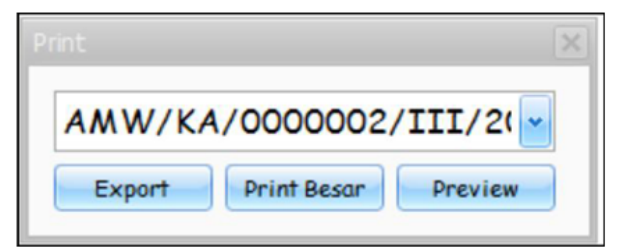

Gambar. 9. Menu Cetak Invoice

\section{PRototype II}

Merupakan tahap kedua dari pengembangan prototyping yang mana merupakan hasil feedback (umpan balik) dari prototype pertama yang terdapat masukkan saran dari pemilik travel agent yang melakukan uji coba pada terhadap prototype pertama, terdapat perubahan fitur baru pada sistem "Aplikasi Untuk Sistem Administrasi Travel Agent ".

Hasil uji coba tahap ke 2, setelah melakukan pembuatan prototype kedua selesai, maka dilakukan uji coba sekali lagi kepada pemilik agent travel, yang pada tahap sebelumnya telah terdapat saran untuk dilakukan penambahan fitur baru pada aplikasi dari sistem lama yang telah ada, setelah pemilik agent mencoba prototype kedua ini dan beberapa pengguna karyawan travel agent. Maka pada tahap ini aplikasi diharapkan telah memberikan feedback, yang baik dalam fungsionalitas program maupun secara tampilan program. Feedback yang telah diberikan kepada pemilik agent digunakan sebagai pertimbangan perbaikan pada prototype kedua ini telah mencapai hasil yang telah diminta lebih baik dari sistem prototype lama. Berikut merupakan hasil pertimbangan dari feedback user pemilik travel agent yang digunakan sebagai pertimbangan dalam prototype kedua.

Pada uji coba tahap pertama telah ditambahkan menu untuk melakukan login untuk masuk kedalam aplikasi, selain pemilik dari travel agent pegawai maupun staff yang bertugas juga dapat melakukan login kedalam aplikasi namun terdapat keterbatasan perbedaan menu yang dapat diakses oleh pegawai dan staff yang sedang bertugas dengan pemilik travel agen.

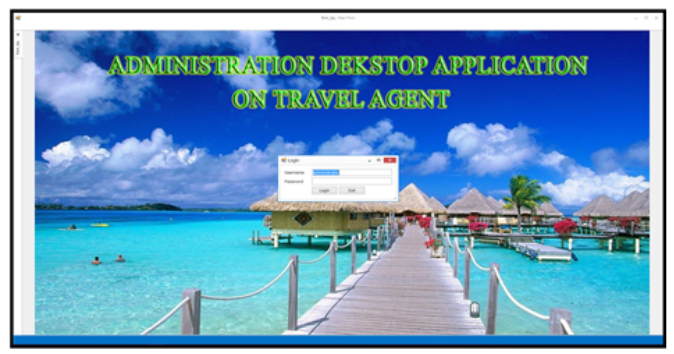

Gambar. 10. Halaman Menu Login Aplikasi
Berikut merupakan hasil dari pengembangan dari prototype yang pertama dan telah di tambahkan pada menu master setiap kategori yang dibutuhkan pada travel agent.

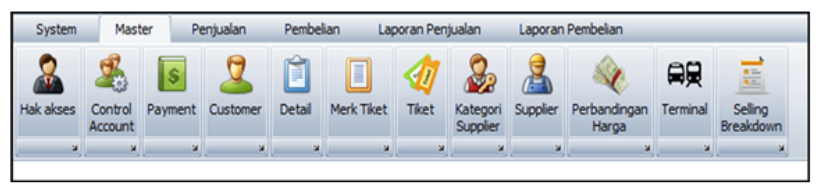

Gambar. 11. Menu Master

Berikut merupakan hasil dari pengembangan dari prototype yang pertama dan telah di tambahkan pada menu penjualan setiap kategori yang dibutuhkan pada travel agent.

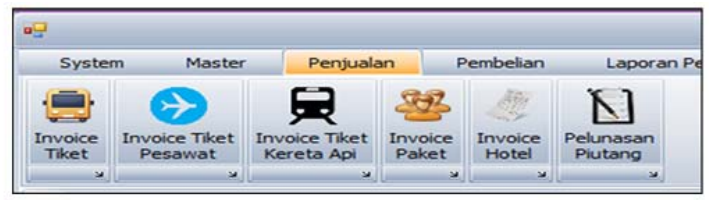

Gambar. 12. Menu Penjualan

Berikut merupakan hasil dari pengembangan dari prototype yang pertama dan telah di tambahkan pada menu laporan penjualan setiap kategori yang dibutuhkan pada travel agent.

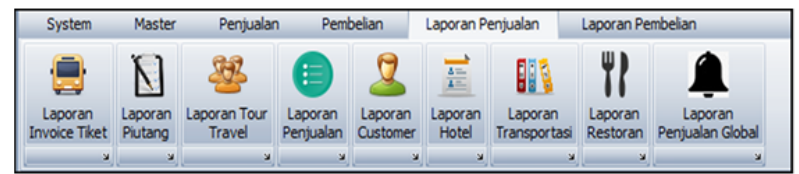

Gambar. 13. Menu Laporan Penjualan

\section{UJI COBA}

Pada bab uji coba ini test uji coba yang telah berhasil pernah dilakukan yaitu dengan pemilik dari travel agent itu sendiri umpan balik dari pemilik travel serta hasil tahap uji coba tahap pertama telah ditambahkan dan telah disempurnakan pada hasil uji coba pada tahap prototype kedua, sesuai dengan permintaan kebutuhan pengunaan dan penambahan fitur-fitur dari travel agent.

1) Telah ditambahkan saran dari pemilik agent pada aplikasi, menu-menu baru pada aplikasi sesuai dengan kebutuhan proses pada agent.

2) Telah ditambahkan saran dari pemilik agent pada aplikasi, detail nominal jumlah uang yang dikeluarkan pelanggan pada nota invoice.

3) Telah ditambahkan saran dari pemilik agent pada aplikasi, detail keterangan jumlah penumpang dan kategori penumpang pada nota invoice.

4) Telah ditambahkan saran dari pemilik agent pada aplikasi, ketika melakukan penjualan pada nota invoice pesawat telah terdapat keterangan detail dari nomer, kode penerbangan, tujuan bandara, detail kategori penumpang dan detail dari bagasi pada nota invoice.

5) Telah ditambahkan saran dari pemilik agent pada aplikasi, penambahan untuk melakukan cetak detail untuk rundown acara untuk dapat diketahui oleh pemilik pada 
saat proses cetak telah terdapat detail untuk penjualan paket wisata.

Pada uji coba ini telah ditambahkan pada program sesuai dengan kebutuhan pada travel agent, dan telah ditambahkan pada saat melakukan proses cetak invoice ataupun pada saat melakukan proses input pada aplikasi pengguna dapat melakukan penjualan tiket secara pulang dan pergi sedangkan pada sistem sebelumnya yang pernah ada hanya dapat melakukan pembelian tiket secara satu pembelian tiket saja.

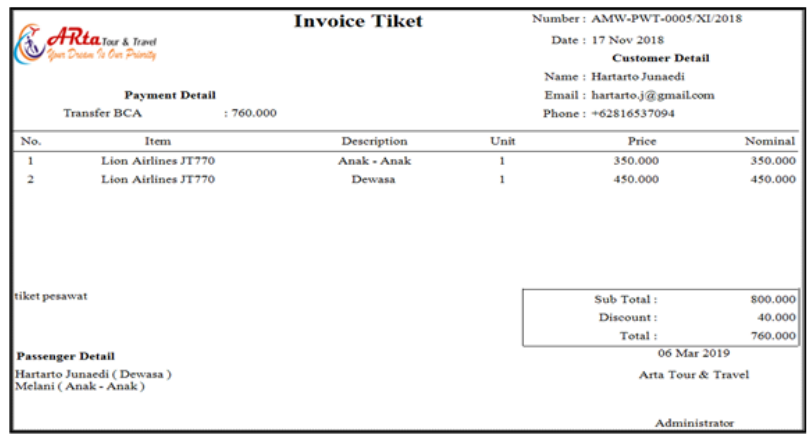

Gambar. 14. Contoh Invoice Tiket Pesawat

Pada uji coba ini telah ditambahkan pada program sesuai dengan kebutuhan pada travel agent, dan telah ditambahkan pada aplikasi pada saat melakukan proses cetak invoice voucher tiket pembeli dapat melihat kode pembelian dari tiket pesawat yang dibeli seta dapat mengetahui tanggal dan jam keberangkatan dari pesawat, serta juga dapat mengetahui kategori dari penumpang dewasa ataupun anakanak.

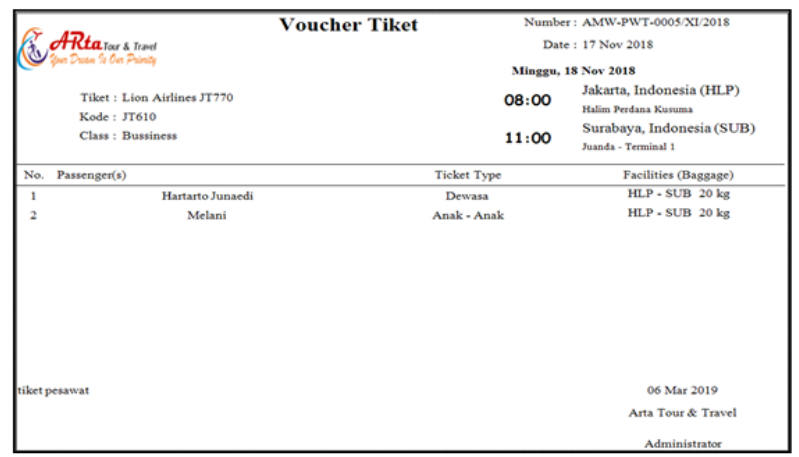

Gambar. 15. Contoh Invoice Voucher Tiket Jadwal Keberangkatan

Pada uji coba ini telah ditambahkan pada program sesuai dengan kebutuhan pada travel agent, dan telah ditambahkan pada saat melakukan proses cetak invoice ataupun pada saat melakukan proses input pada aplikasi pengguna dapat melakukan penjualan tiket secara pulang dan pergi sedangkan pada sistem sebelumnya yang pernah ada hanya dapat melakukan pembelian tiket secara langsung hanya dapat melakukan satu transaksi pembelian tiket saja, selain itu pada cetak invoice voucher tiket yang baru ini juga telah terdapat penambahan untuk keterangan tiket jenis, kode penerbarangan pesawat, class pesawat, dan keterangan dari bandara yang akan dituju maupun bandara yang akan digunakan sebagai tempat keberangkatan, dan detail dari berat bagasi yang akan dibawa penumpang.

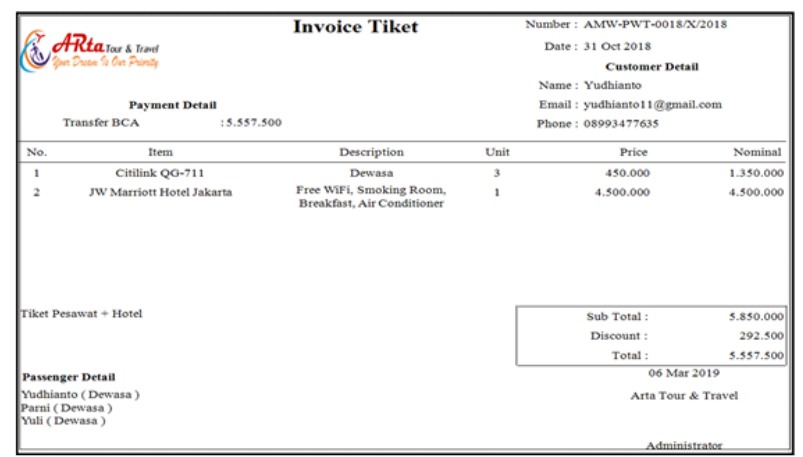

Gambar. 16. Contoh Invoice Tiket Pesawat + Hotel

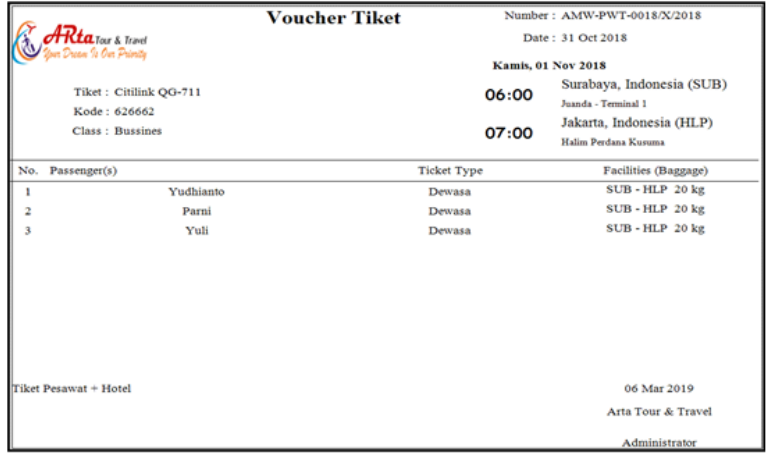

Gambar. 17. Contoh invoice Voucher Tiket Detail Penumpang

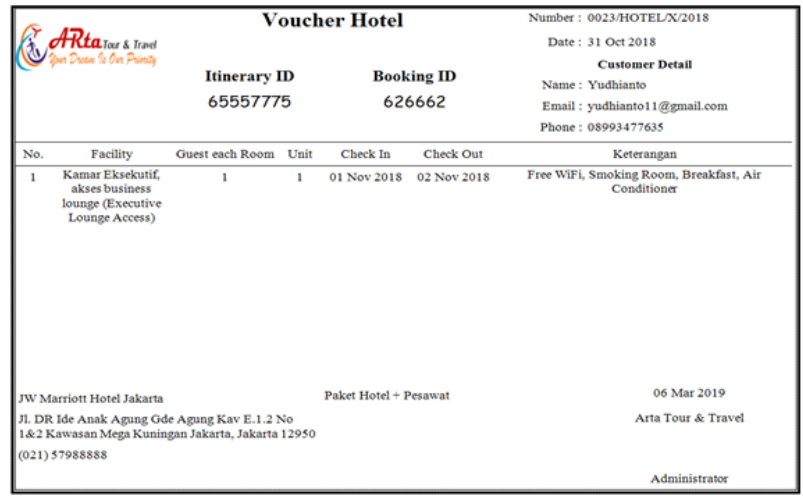

Gambar. 18. Contoh Invoice Voucher Paket Hotel

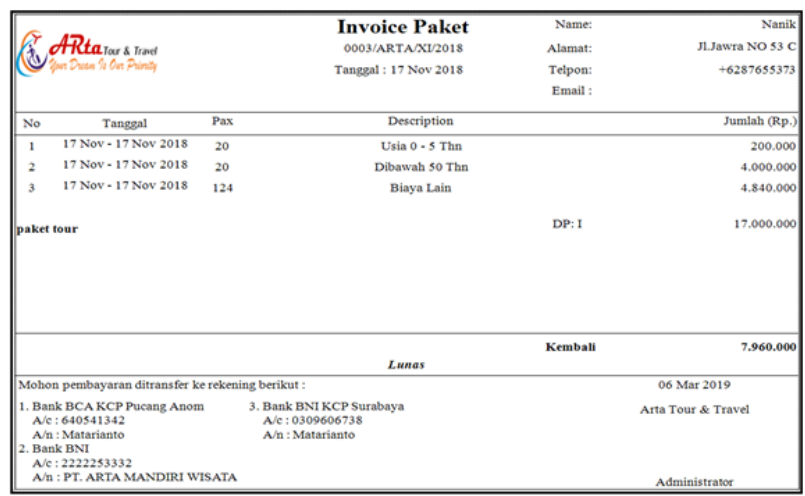

Gambar. 19. Contoh Invoice Paket Liburan 
JOURNAL OF INFORMATION SYSTEM, GRAPHICS, HOSPITALITY AND TECHNOLOGY

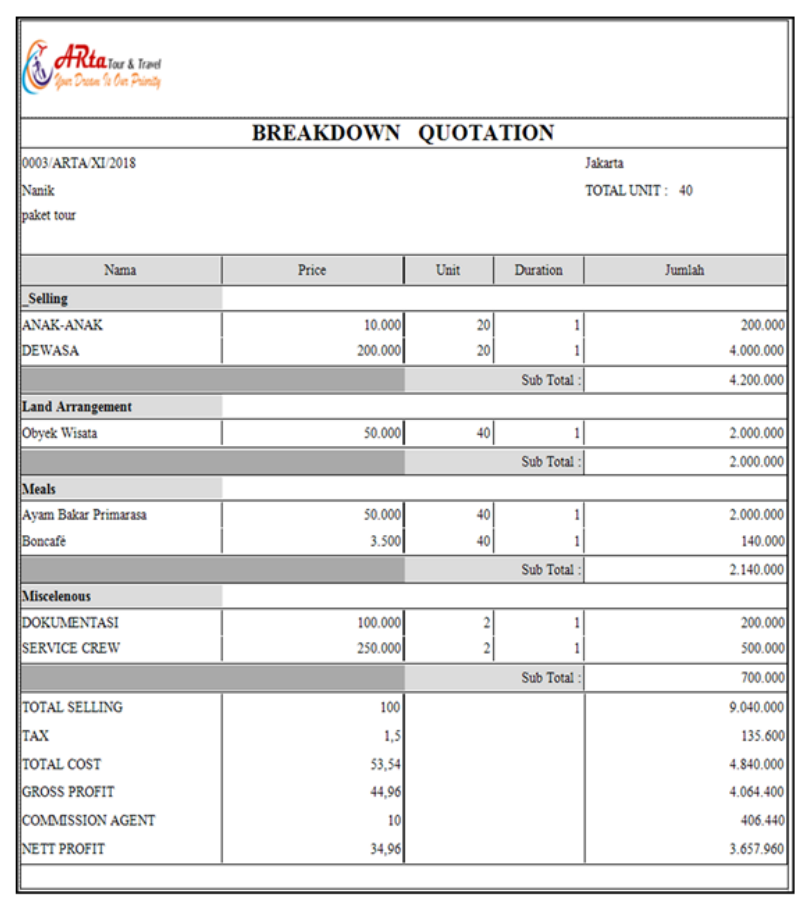

Gambar. 20. Contoh Invoice Paket Detail Breakdown Perjalanan

\section{Kesimpulan}

Dari kesimpulan yang didapatkan berdasarkan pengembangan aplikasi selama proses pembuatan Penelitian ini. Kesimpulan-kesimpulan yang didapatkan antara lain:

1) Membantu pemilik agen travel dan pekerjaannya untuk mengelolah penjualan tiket menjadi lebih cepat dan akurat.

2) Membantu pelanggan dalam menemukan tempat wisata dan harga tiket yang cocok dengan pelanggan.

3) Membantu pelanggan dalam menemukan tempat wisata dan harga tiket yang cocok dengan pelanggan.

4) Penggunaan membantu mempermudah melakukan proses reservasi customer.

Berikut adalah beberapa saran yang dapat digunakan untuk pengembangan aplikasi dekstop administrasi pada travel agent ini lebih lanjut:

1) Menambahkan fitur penjualan tiket secara online.

2) Membantu website sistem penjualan tiket tour.

3) Menambahkan dan mengembangkan lagi dari fitur-fitur yang sudah ada untuk menjadi lebih lengkap lagi.

\section{UCAPAN TERIMA KASIH / ACKNOLEDGMENT}

Penulis mengucap rasa bersyukur kepada Allah SWT atas rahmat-Nya sehingga dapat menyelesaikan Penelitian ini dengan baik dan tepat waktu. Penulis juga mengucapkan terima kasih kepada keluarga, para dosen, dan teman-teman yang selalu mendukung dan membantu memberikan pengarahan kepada penulis.

\section{DAFTAR PUSTAKA}

[1] Adi Kurniadi, Pemprograman Visual Basic, Elex Media Komputindo, Jakarta, 2000.

[2] Chua, CK., KF Leong, CS Lim. 2010. Thrid Edition Rapid Prototyping: Principles and Applications. World Scientific Publishing Co. Pte. Ltd.
[3] Ladjamudin, A., 2005, Analisis dan Desain Sistem Informasi, Graha Ilmu, Yogyakarta.

[4] Moch, Azam. Pengertian MySQL Beserta Fungsi dan Sejarah Terbentuknya MySQL Secara Lengkap.

[5] Margaret Rouse Definition of MySQL

[6] Pressman, R.S., 2002, Rekayasa Perangkat Lunak, edisi I, (diterjemahkan oleh: Hamaningrum, L., N.), Andi Offset Yogyakarta.

[7] Pressman, Roger. 2005. Software Engineering: A Practitioner's

[8] Approach. New York: McGraw-Hill

[9] Saifulloh, Rifa'i, 2013. Pengertian dan sejarah MYSQL [Online]

[10] Available at: http://www.pengertianku.net/2017/12/pengertian-phpdan-kegunaannya.html

[11] Wahana, K.,2013, Visual Basic 2012 Source Code, Andi Offset, Yogyakarta. 